\title{
Comparative Study Regarding the Surface Roughness of Highly Viscous Flowable Composites After Immersion in Acidic Drinks
}

\author{
IRINA NICA ${ }^{1}$, SIMONA STO LERIU1*, GALINA PANCUㄹ, ADRIANA MUNTEANU², CLAUDIU TOPOLICEANU1', ALEXANDRU IOVAN², \\ EMILIA DIMBU ${ }^{1}$, SORIN ANDRIAN ${ }^{1}$ \\ ${ }^{1}$ Grigore T. Popa University of Medicine and Pharmacy lasi, Faculty of Dental Medicine,16 Universitatii Str., 700115, Iasi, Romania \\ ${ }^{2}$ Gheorghe Asachi Technical University of Iasi, Faculty of Machine Manufacturing and Industrial Management, 67 Dimitrie \\ Mangeron Blvd., 700050, Iasi, Romania \\ ${ }^{3}$ Dental office, 127 Pacurari Str., 700523, lasi, Romania
}

\begin{abstract}
The aim of the present study was to assess, by profilometry, the effect of different immersion regimes in Coca-Cola drink on the surface roughness of two highly viscous flowable composite resins. The studied materials were Gradia Direct LoFlo (GC Corporation, Tokyo, Japan) and Micro Esthetic flow-viscous (Bisico, Germany). Fifteen cylindrical samples having the of $5 \mathrm{~mm}$ and the thickness of $2 \mathrm{~mm}$ were made from each material using plastic molds placed on glass plates. The samples were light-cured for 40s on both sides through the glass plates, to ensure complete polymerization of the material. They were divided into two groups as follows: Group I. Gradia Direct LoFlo and Group II. Micro Esthetic flow-viscous. Specimens of each group were then randomly divided into 5 subgroups. In subgroup A (control group) 4 samples were kept only in artificial saliva. In subgroups B-E (each having 4 samples) the samples were immersed in CocaCola drink according to 4 different protocols. The mean values of roughness parameters, Ra, were calculated. The Kolmogorov-Smirnov normality test was used to determine the distribution of data in groups. ANOVA and Tukey post hoc statistical tests were used to compare the results from the groups. For both materials, the highest surface roughness was determined for the samples that were submerged 7 times/day in Coca Cola. The assessment of surface microstructure of the samples, after immersion, revealed for both materials a statistically significant increase of Ra values.
\end{abstract}

Keywords: flowable composite, acidic drink, profilometry

Resin composites are an excellent choice for minimally invasive dental procedures and therefore they allow to maintain maximum of tooth tissues. They are considered a suitable direct posterior ûlling material showing good long-term clinical survival [1, 2].

The continuous development of resin composites has led to formulations designed to further simplify the ûlling procedure, to provide better mechanical properties, to reduce the effect of polymerization shrinkage stresses and to improve aesthetics. Marginal defects of composite ûllings are often thought to be caused by poor adaptation of the restorative material to the cavity walls [3]. To avoid these defects, particularly in posterior teeth, the use of ûowable composites has been advocated due to their ability to wet and adapt well to cavity margins and walls $[4,5]$. However, ûowable composites have a lower ûller content and usually weaker mechanical properties than conventional composites. Therefore, flowable composites can be applied as a restoration in minimally invasive occlusal cavity preparations, as pit and fissure sealants, as minimally invasive Class II restorations, and as non-carious cervical lesions restorations [6].

Recently, a new type of highly filled ûow able composite has been developed. When comparing to conventional paste-type composites, the highly flled fowable resin contains nano-sized fllers, the surface of which has been modiûed to provide a reduced viscosity for placement but allows the composite to be used in load-bearing restorations [ 7,8$]$.

In the oral environment, the composites are subjected to the action of various physical, chemical and mechanical agents. Particular attention was paid to the influence of extrinsic acidic challenges on the surface microstructure of composite resins [9-11].
Frequent consumption of carbonated drinks, alcohol, coffee, tea or red wine can affect some physical properties of composites resins such as surface roughness and microhardness, thus undermining the quality of restorations and their resistance to dissolution and disintegration [1214].

The effect of these acidic challenges depends on the structure of restorative materials, such as organic matrix, filler load, filler distribution and silane treatment effect on fillers $[15,16]$.

The aim of the present study was to assess, by profilometry, the effect of different immersion regimes in Coca-Cola drink, on the surface roughness of two highly viscous flowable composite resins.

\section{Experimental part}

The materials used in the present study were:

GRADIA DIRECT LoFlo is a light-cured, high viscosity flowable microfilled hybrid composite for simple restorations. It takes advantage of GC's new HDR (High Density Radiopaque Pre-polymerized Filler) technology. This technology allows for excellent radiopacity while providing physical properties (strength and wear) like traditional composites making it ideal as a final restorative in all primary and conservative permanent restorations. Its highly filled formula ensures exceptionally low shrinkage, this along with its optimal flow characteristics, ensures better adaptation to proximal and cervical walls and internal line angels reducing the risk of contraction stress and microleakage GRADIA DIRECT LoFlo has indication for the following: restoration of Class I, II, III, IV and V cavities (particularly for small Class I cavities/shallow Class V cavities/other small cavities), restoration of root 


\begin{tabular}{|c|c|c|c|c|c|}
\hline Material & Manufacturer & $\begin{array}{c}\text { Type/ BatchNo/ } \\
\text { Shade }\end{array}$ & $\begin{array}{c}\text { Organic } \\
\text { matrix }\end{array}$ & Filler type & $\begin{array}{c}\text { Filler load } \\
\text { (wt \%) }\end{array}$ \\
\hline $\begin{array}{c}\text { GRADIA } \\
\text { DIRECT } \\
\text { LoFlo }\end{array}$ & $\begin{array}{c}\text { GC } \\
\text { Torporation, }\end{array}$ & $\begin{array}{c}\text { Microfilled, } \\
\text { hybrid/ Lot } \\
1707141 / \mathrm{A} 3\end{array}$ & $\begin{array}{c}\text { UDMA, } \\
\text { dimethacrylat } \\
\text { e component } \\
\text { (trade secret), }\end{array}$ & $\begin{array}{c}\text { Fluoro-alumino- } \\
\text { silicate glass } \\
\text { filler, HDR pre- } \\
\text { polymerized } \\
\text { fillers }\end{array}$ & $40 \mathrm{wt} \%$ \\
\hline $\begin{array}{c}\text { MICRO } \\
\text { ESTHETIC } \\
\text { Flow-viscous }\end{array}$ & $\begin{array}{c}\text { Bisico, } \\
\text { Germany }\end{array}$ & $\begin{array}{c}\text { Nano } \\
\text { opimized, micro } \\
\text { hybrid/Lot } \\
007800 / \text { A3 }\end{array}$ & $\begin{array}{c}\text { UDMA, } \\
1.4- \\
\text { Butandioldime } \\
\text { thacrylate } \\
\text { Bis-GMA free }\end{array}$ & $\begin{array}{c}\text { alumino-silicate } \\
\text { glass filler }\end{array}$ & $72 \mathrm{wt} \%$ \\
\hline
\end{tabular}

Bis-GMA: Bisphenol A diglycidyl ether dimethacrylate; UDMA: Urethandimethacrylate

Table 1

DESCRIPTION OF THE RESTORATIVE MATERIALS USED IN THE STUDY surface caries, restorations in deciduous teeth, filling tunnel shaped cavities, sealing hypersensitive areas, composite restorations repair.

MICRO ESTHETIC flow-viscous is a flowable, highly viscous, highly radiopaque $(210 \% \mathrm{AL})$, light-curing nanohybrid composites for restoring small class I-III cavities, and class $V$ cavities. It can be used for fissure sealings, corrections of enamel defects, blocking out of undercuts, and minor shape and color corrections to the enamel.

The high filler content of 72 wt $\%$ glass filler particles ensures the high viscosity of the flow composite. There is no running or dripping of the flow composite and it allows a highly precise application. This makes minimal invasive class $\mathrm{V}$ restorations easier. Excellent mechanical properties such as low polymerization shrinkage, an extremely high abrasion resistance and high flexural strength are further key properties. As this new composite does not contain bis-GMA the patient's sensitivity is reduced and its biocompatibility is increased. The description of the restorative materials used in the study is presented in table 1.

Fifteen cylindrical samples having the diameter of $5 \mathrm{~mm}$ and the thickness of $2 \mathrm{~mm}$ were made using plastic molds. The conformers were placed in tight contact with a celluloid matrix between two glass plates, in order to obtain a smooth, flat and a surface free of pores. The samples were lightcured for $40 \mathrm{~s}$ on both sides through glass plate to ensure complete polymerization of the material, using a light source Amarys W ireless LED (Tosi). The source emits cold radiation with a wavelength range of $430-485 \mathrm{~nm}$, has a maximum power of $700 \mathrm{~mW} / \mathrm{cm}^{2}$ and provides a 3 $\mathrm{mm}$ polymerization depth.

After removing the samples from the molds, they were divided into two groups: Group I. Gradia Direct LoFlo and Group II. Micro Esthetic flow-viscous. Then the samples from each group were randomly divided into five subgroups. In subgroup A (control) 4 samples were kept only in artificial saliva. In B-E subgroups the samples (4 in each subgroup), were submitted to 4 different immersion protocols. Each sample of the control group was completely immersed artificial saliva ( $25 \mathrm{~mL}$ ), for seven days, in a hermetically sealed container at room temperature. Artificial saliva from each recipient was daily refreshed. The chemical composition of the artificial saliva solution

Table 2

THE CHEMICAL COMPOSITION OF THE ARTIFICIAL SALIVA SOLUTION

\begin{tabular}{|c|c|}
\hline Chemical compound & Weight \\
\hline $\mathrm{KCl}$ & $1.5 \mathrm{~g}$ \\
\hline $\mathrm{NaHCO}_{3}$ & $1.5 \mathrm{~g}$ \\
\hline $\mathrm{NaH}_{2} \mathrm{PO}_{4}$ & $0.5 \mathrm{~g}$ \\
\hline $\mathrm{KSCN}$ & $0.5 \mathrm{~g}$ \\
\hline Lactic acid & $0.7 \mathrm{~g}$ \\
\hline
\end{tabular}

REV.CHIM. (Bucharest) $\bullet 70 \diamond$ No. 6 \2019 proposed by Brettetal., for one liter of solution, $\mathrm{pH}=6.7$, is shown in table $2[17,18]$.

The specimens from the other 4 subgroups were kept in $25 \mathrm{~mL}$ of Coca-Cola (S.C. Coca-Cola HBC Romania S.R.L., Voluntari, Ilfov) with a $\mathrm{pH}=2.5$, as follows: subgroup Bonce a day, subgroup C-3 times a day, subgroup D- 5 times a day, subgroup $\mathrm{E}-7$ times a day.

The specimens were completely immersed in CocaCola for $5 \mathrm{~min}$ and the container was continuously stirred, to ensure complete contact of the samples with the immersion medium. The Coca-Cola drink was changed after each immersion. When they were not subjected to immersion, the samples from subgroups B, C, D, and E were kept in artificial saliva. Some studies have shown that the most important changes in physical properties occur within the first 7 days of exposure to acidic solutions, and for this reason the immersion protocol was performed over a 7-day period. Atthe end of the protocol, the samples were washed with distilled water and dried using air spray.

For surface roughness assessment, all the samples were analyzed using the Surface Roughness Measuring Tester S) -210, Mitutoyo, J apan. Regarding the roughness standard, the evaluation was based on ISO1997 applicable standards. Ten traces were registered in different areas with a tip load of $0.75 \mathrm{mN}$, a tip diameter of $2 \mu \mathrm{m}$, a scanning speed of 0.5 $\mathrm{mm} / \mathrm{s}$ and a cut-off length $(\lambda \mathrm{c})$ of $0.25 \mu \mathrm{m}$. The roughness parameters were calculated and the mean arithmetic deviation, $\mathrm{Ra}$, of the assessed profile was used. The Kolmogorov-Smirnov normality test was used to determine the distribution of data in groups. ANOVA and Tukey post hoc statistical tests were used to compare the results in groups.

\section{Results and discussions}

The mean Ra values obtained by quantitative assessment of samples surface using profilometry and standard deviation (SD) are presented in figure 1.

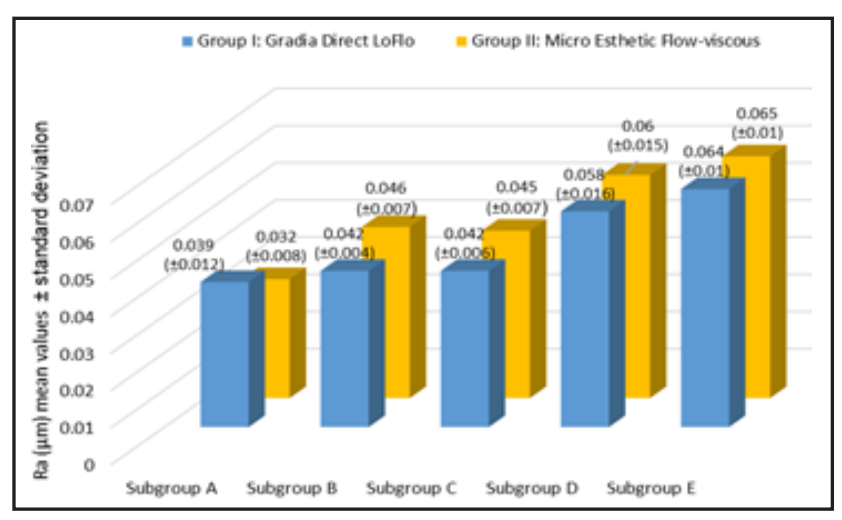

Fig. 1. Mean values of Ra parameter $( \pm S D)$ in control groups and after immersion in Coca-Cola, for both tested materials 
One-Sample Kolmogorov-Smirnov Test

\begin{tabular}{|ll|r|r|}
\hline & & $\begin{array}{r}\text { gradia direct } \\
\text { loflo }\end{array}$ & $\begin{array}{c}\text { micro esthetic } \\
\text { flow viscous }\end{array}$ \\
\hline $\mathrm{N}$ & 75 & 75 \\
Normal Parameters & Mean & .04991 & .04937 \\
& Std. Deviation & .014541 & .015526 \\
Most Extreme Differences & Absolute & .152 & .135 \\
& Positive & .152 & .135 \\
& Negative & -.103 & -.068 \\
Kolmogorov-Smirnov $\mathrm{Z}$ & & 1.318 & 1.171 \\
Asymp. Sig. (2-tailed) & & .062 & .129 \\
\hline
\end{tabular}

Table 3

THE KOLMOGOROV-SMIRNOV NORMALITY TEST RESULT

a. Test distribution is Normal

b. Calculated from data.

For both studied materials the lowest Ra values were obtained in subgroup A as follows $\mathrm{Ra}=0.039 \mu \mathrm{m}$ for Gradia Direct LoFlo and Ra $=0.032 \mu \mathrm{m}$ for Micro Esthetic Flowviscous. In subgroup B, increased Ra values (0.46 $\mu \mathrm{m})$ were found only for Micro Esthetic Flow-viscous while for Gradia Direct LoFlo the Ra values (0.042) were closed to those of the control group. In subgroup C, for both materials, Ra values remained almost the same as in subgroup $B$. An obvious increase of Ra values was observed in subgroups $D$ and $E$ for both composite resins. The result of the Kolmogorov-Smirnov normality test showed that in all groups the data were normal distributed $(p>0.05)$ (table 3).

In order to compare the results in groups, ANOVA and Tukey post hoc statistical tests were used (tables 4, 5 and 6).

In group I - Gradia Direct LoFlo, the statistical analysis revealed that the values were not statistically significant when comparing subgroup $A$ (control) to subgroup $B$ and subgroup ( $p>0.05$ ). Also, when comparing subgroups $B$ and $C$, respectively $D$ and $E$, there were no statistically significant results. However, significant values were obtained when comparing subgroup $A$ with subgroups $D$ and $E(p<0.05)$.

In group II - Micro Esthetic Flow-viscous, statistically significant values were recorded when comparing subgroup A to all other subgroups. For this material the strongest statistical significance was determined when comparing subgroup $A$ to subgroups $D$ and $E$. As for the previous material, no significant values were obtained for Micro Esthetic Flow-viscous when comparing subgroup $B$ to $C$ and respectively subgroup $D$ to $E$.

\begin{tabular}{|ll|r|r|r|r|r|}
\multicolumn{1}{l|}{ ANOVA } \\
\hline & \multicolumn{1}{c|}{$\begin{array}{c}\text { Sum of } \\
\text { Squares }\end{array}$} & \multicolumn{1}{c|}{ df } & Mean Square & \multicolumn{1}{c|}{$\mathrm{F}$} & \multicolumn{1}{c|}{ Sig. } \\
\hline gradia direct loflo & Between Groups & .008 & 4 & .002 & 16.971 & .000 \\
& Within Groups & .008 & 70 & .000 & & \\
& Total & .016 & 74 & & & \\
\hline micro esthetic flow & Between Groups & .010 & 4 & .003 & 24.487 & .000 \\
viscous & Within Groups & .007 & 70 & .000 & & \\
& Total & .018 & 74 & & & \\
\hline
\end{tabular}

Multiple Comparisons

Dependent Variable: gradia direct loflo

\begin{tabular}{|c|c|c|c|c|c|c|c|}
\hline & \multirow[b]{2}{*}{ (1) category } & \multirow[b]{2}{*}{ (N) category } & \multirow{2}{*}{$\begin{array}{c}\text { Mean } \\
\text { Difference } \\
(\mathrm{I}-\mathrm{J})\end{array}$} & \multirow[b]{2}{*}{ Std. Error } & \multirow[b]{2}{*}{ Sig. } & \multicolumn{2}{|c|}{$95 \%$ Confidence Interval } \\
\hline & & & & & & Lower Bound & Upper Bound \\
\hline \multirow[t]{20}{*}{ Tukey HSD } & \multirow[t]{4}{*}{ Subgroup A } & Subgroup B & .003000 & .003890 & .938 & .01389 & .00789 \\
\hline & & Subgroup $C$ & -.002867 & .003890 & .947 & .01376 & .00803 \\
\hline & & Subgroup D & $-.019200^{\circ}$ & .003890 & .000 & .03009 & .00831 \\
\hline & & Subgroup $E$ & $.025133^{\circ}$ & .003890 & .000 & .03603 & .01424 \\
\hline & \multirow[t]{4}{*}{ Subgroup B } & Subgroup A & .003000 & .003890 & .938 & .00789 & .01389 \\
\hline & & Subgroup $C$ & .000133 & .003890 & 1.000 & .01076 & .01103 \\
\hline & & Subgroup D & $-.016200^{\circ}$ & .003890 & .001 & .02709 & .00531 \\
\hline & & Subgroup $E$ & $.022133^{\circ}$ & .003890 & .000 & .03303 & .01124 \\
\hline & \multirow[t]{4}{*}{ Subgroup C } & Subgroup $A$ & .002867 & .003890 & .947 & .00803 & .01376 \\
\hline & & Subgroup $B$ & -.000133 & .003890 & 1.000 & .01103 & .01076 \\
\hline & & Subgroup D & $.016333^{\circ}$ & .003890 & .001 & .02723 & .00544 \\
\hline & & Subgroup E & $.022267^{\circ}$ & .003890 & .000 & .03316 & .01137 \\
\hline & \multirow[t]{4}{*}{ Subgroup D } & Subgroup $A$ & $.019200^{\circ}$ & .003890 & .000 & .00831 & .03009 \\
\hline & & Subgroup B & $.016200^{\circ}$ & .003890 & .001 & .00531 & .02709 \\
\hline & & Subgroup C & $.016333^{\circ}$ & .003890 & .001 & .00544 & .02723 \\
\hline & & Subgroup E & -005933 & .003890 & .550 & .01683 & .00496 \\
\hline & \multirow[t]{4}{*}{ Subgroup E } & Subgroup $A$ & $.025133^{\circ}$ & .003890 & .000 & .01424 & .03603 \\
\hline & & Subgroup B & $.022133^{\circ}$ & .003890 & .000 & .01124 & .03303 \\
\hline & & Subgroup C & $.022267^{\circ}$ & .003890 & .000 & .01137 & .03316 \\
\hline & & Subgroup D & .005933 & .003890 & .550 & .00496 & .01683 \\
\hline
\end{tabular}

*. The mean difference is significant at the 0.05 level.
Table 4

ANOVA STATISTICAL TEST RESULT
Table 5

TUKEY POST HOC STATISTICAL TEST RESULT FOR GRADIA DIRECT LOFLO 
Multiple Comparisons

Dependent Variable: micro esthetic flow viscous

\begin{tabular}{|c|c|c|c|c|c|c|c|}
\hline & \multirow[b]{2}{*}{ (1) category } & \multirow[b]{2}{*}{ (D) category } & \multirow{2}{*}{$\begin{array}{c}\text { Mean } \\
\text { Difference } \\
(1-J)\end{array}$} & \multirow[b]{2}{*}{ Std. Error } & \multirow[b]{2}{*}{ Sig. } & \multicolumn{2}{|c|}{$95 \%$ Confidence Interval } \\
\hline & & & & & & Lower bound & Upper Bound \\
\hline \multirow[t]{20}{*}{ Tukey HSD } & \multirow[t]{4}{*}{ Subgroup A } & Subgroup B & $.014000^{\circ}$ & .003763 & .004 & -.02454 & .00346 \\
\hline & & Subgroup $C$ & $.013867^{\circ}$ & .003763 & .004 & -.02440 & .00333 \\
\hline & & Subgroup D & $-.027867^{\circ}$ & .003763 & .000 & -.03840 & .01733 \\
\hline & & Subgroup E & $=.033467^{\circ}$ & .003763 & .000 & $=.04400$ & .02293 \\
\hline & \multirow[t]{4}{*}{ Subgroup B } & Subgroup $A$ & $.014000^{\circ}$ & .003763 & .004 & .00346 & .02454 \\
\hline & & Subgroup C & .000133 & .003763 & 1.000 & -.01040 & .01067 \\
\hline & & Subgroup D & $=.013867^{\circ}$ & .003763 & .004 & $=.02440$ & .00333 \\
\hline & & Subgroup $E$ & $-.019467^{\circ}$ & .003763 & .000 & -03000 & .00893 \\
\hline & \multirow[t]{4}{*}{ Subgroup C } & Subgroup A & $.013867^{\circ}$ & .003763 & .004 & .00333 & .02440 \\
\hline & & Subgroup B & -000133 & .003763 & 1.000 & -01067 & .01040 \\
\hline & & Subgroup D & $-.014000^{\circ}$ & .003763 & .004 & -.02454 & .00346 \\
\hline & & Subgroup $E$ & $-.019600^{\circ}$ & .003763 & .000 & -.03014 &., 00906 \\
\hline & \multirow[t]{4}{*}{ Subgroup D } & Subgroup A & $.027867^{\circ}$ & .003763 & .000 & .01733 & .03840 \\
\hline & & Subgroup B & $.013867^{\circ}$ & .003763 & .004 & .00333 & .02440 \\
\hline & & Subgroup C & $.014000^{\circ}$ & .003763 & .004 & .00346 & .02454 \\
\hline & & Subgroup E & $=.005600$ & .003763 & .574 & -.01614 & .00494 \\
\hline & \multirow[t]{4}{*}{ Suboroup E } & Subgroud $\mathrm{A}$ & $.033467^{\circ}$ & .003763 & .000 & .02293 & .04400 \\
\hline & & Subgroup B & $.019467^{\circ}$ & .003763 & .000 & .00893 & .03000 \\
\hline & & Subgroup C & $.019600^{\circ}$ & .003763 & .000 & .00906 & .03014 \\
\hline & & Subgroup D & .005600 & .003763 & .574 & $=.00494$ & .01614 \\
\hline
\end{tabular}

Table 6

TUKEY POST HOC STATISTICAL TEST RESULT FOR MICRO ESTHETIC FLOW-VISCOUS

* The mean difference is significant at the 0.05 level.

These observations confirm that the surface roughness of the studied materials increased with the increase of the number of immersions, the highest mean value of the Ra parameter being detected after 7 immersions/day.

This could lead to the idea that the intake of carbonated beverages, even in small quantities but with increased frequency during the day and for several consecutive days, alters the surface condition of composite resins. Our results are in agreement with other studies which showed that the exposure to acidic drinks and food intake induces the chemical dissolution of restorative materials, thus increasing the roughness of the superficial layer. Some studies have shown that a residual surface roughness may induce bacterial plaque retention [19-21]. pH of Coca-Cola is very low. More than that, this soft drink contains phosphoric acid which is an inorganic and strong acid. This association of a low $\mathrm{pH}$ and a strong inorganic acid could have caused a very aggressive attack on the surface of flowable composite, which led to an increase in the surface roughness. The roughness parameter Ra represents the mean arithmetic deviation of the assessed profile. The results showed that the Ra values, of both composite resins immersed in Cola-Cola drink, increased as the number of immersions increased. The higher the number of immersions the higher was the impact on the restorative materials. Our findings are in agreement with the results of other studies [22, 23].

Composites containing small filler particles are more homogeneous and their particles are less prominent on the surface, thus resulting a lower surface roughness. The filler type, size and quantity of the particles strongly influence the properties and quality of composite resins. The particles that are stripped outfrom the surface are very small, leaving small holes which produce an obvious increase in roughness. These findings are similar with that ones from other studies [24, 25]. Some authors suggested that relatively higher filler loading increases the stability of composite resin surface against low pH conditions [2628]. However, still a not significantly increase in surface roughness of Micro Esthetic flow viscous samples when comparing to Gradia Direct LoFlo was noticed.
These changes may be due to water sorption by composite resin under acidic conditions leading to an increase in roughness, as it is composed mainly of monomers that are more susceptible to hydrolysis, like dimethacrylates [29-31]. The chemistry and the structure of polymer matrix are the most important factors influencing sorption and solubility of dental composites. The differences in water absorption of polymer network depend on monomer type (TEGDMA > Bis-GMA > UDMA $>$ Bis-EMA) [32]. Both composites materials used in the present study contain UDMA (table 1), which is one of the most hydrophilic monomers. The organic matrix of resin composites is known to absorb a small percentage of water from the oral environment, which may alter some physical properties. Surface roughness and microhardness of dental composites has been reported to be significantly affected by water sorption and the contact time with the aqueous medium [33]. It is indeed difficult to isolate restorative materials so they can overcome all external challenges and successfully mentain their physical, chemical and mechanical properties.

The containers with Coca-Cola, in which the samples of the two materials were immersed, have been continuously stirred, to reproduce the bubbling conditions from the oral cavity. One can assume that micrometric losses occur in the superficial layer, the material exposing a new surface to the acid attack, and thus corrosion is cyclically repeated. This was also observed in other studies [22, 34]. The nature of the degradation suffered by dental materials and dental hard tissue subsequent to an erosive and cariogenic challenges is very complex. It was observed that surface roughness assessment is an appropriate method to verify small alterations in the superficial layer of composite resins after acid demineralization [35-38].

Even if the new generation of restorative materials serve to fulfill manly the esthetic demands, the effect of frequently consumed carbonated beverages on their stability and longevity needs further research. This in-vitro study thus might recommend that, in terms of resistance to degradation, flowable composite could be the material of choice for restoring teeth affected by erosion. How ever, 
the degradation of materials is not the only factor involved in making this choice. An appropriate clinical case selection should be taken into consideration. Within the limitations of this study it can be concluded that repeated and longterm exposure to acidic beverages potentially affects the surface microstructure of esthetic dental restorative materials.

\section{Conclusions}

The surface condition of the samples from the two evaluated composite materials was affected after their immersion in the acidic medium represented by Coca-Cola drink, compared to the control subgroup. The results of the present study showed that the surface roughness values, of both restorative materials immersed in Coca-Cola, increased directly in proportion to the number of immersions, the highest value being determined for samples submerged in acidic drink 7 times a day. A greater number of immersions in the Cola drink (Coca-Cola) resulted in a higher impact on the restorative materials.

\section{References}

1. BAROUDI, K., RODRIGUES, J.C., J. Clin. Diagn. Res., 9, no.6, 2015, p.18.

2. GHIORGHE, C.A., IOVAN, G, ANDRIAN, S., NICA, I., TOPOLICEANU, C., PANCU, G., Rev. Chim. (Bucharest), 68, no.8, 2017, p.1890. 3. BAYNE, S.C., J. Am. Dent. Assoc., 129, no. 5, 1998, p.567. 4.MITRA, S.B., WU, D., HOLMES, B.N., J. Am. Dent. Assoc., 134, no.10, 2003, p.1382.

5. SACHAN, S., SRIVASTAVA, I., RANJ AN, M., J. Dent. Med. Sci., 15, no.6, 2016, p.71.

6. JAFARZADEH, M., MALEKAFZALI, B., TADAYON, N., FALLAHI, S., J. Dent.,7, no.1, 2010, p.1.

7. KIM, K.H., ONG, J.L., OKUNO, O., J. Prosthet. Dent., 87, no.6, 2002, p.642.

8. IKEDA, I., OTSUKI, M., SADR, A., NOMURA, T., KISHIKAWA, R., TAGAMI, J., Dent. Mater. J., 28, no.6, 2009, p.679.

9.KITASAKO, Y., SADR, A., BURROW, M.F., TAGAMI, J., Aust. Dent. J., 61, no.3, 2016, p.366.

10. SARRETT, D.C., COLETTI, D.P., PELUSO, A.R.,,Dent. Mater., 16, no.1, 2000, p. 62.

11.NICA, I., IOVAN, G., GHIORGHE, A., STOLERIU, S., PANCU, G., ANDRIAN, S., Romanian Journal of Oral Rehabilitation, 7, no. 4, 2015, p.37.

12. HAN, L., OKAMOTO, A., FUKUSHIMA, M., OKIJI, T., Dent. Mater. J., 27, no.3, 2008, p.455.

13. NEAMAT, A.B., HAN, L., OKAMOTO, A., IWAKU, M., J . Esthet. Restor. Dent., 12, no.2, 2000, p.97.

14.TOFAN, N., ANDRIAN, S., STOLERIU, S., NICA, I., MOLDOVANU, A., TOPOLICEANU, C., SOLOMON, O., PANCU, G., Mat. Plast., 55, no. 1, 2018, p. 129.
15. NICA, I., CIMPOESU, N., RUSU, V., ANDRONACHE, M., STEFANESCU, C., Mat. Plast., 49, no.3, 2012, p. 176.

16. POGGIO, C., DAGNA, A., CHIESA, M., COLOMBO, M., SCRIBANTE, A., J. Conserv. Dent.,15, no.2, 2012, p.137.

17. BRETT, C.M.A., TRANDAFIR, F., J. Electroanal. Chem., 572, no.2, 2004, p.347.

18.NICA, I., STOLERIU, S., IOVAN, G., PANCU, G., URSU, L., GEORGESCU, A., ANDRIAN, S., International J ournal of Medical Dentistry, 22, no.4, 2018, p.358.

19. BALAN,A., SAVIN, C., SANDU, A.V., STOLERIU, S., Mat. Plast., 53, no.1, 2016, p.100.

20. STOLERIU, S., IOVAN, G., GEORGESCU, A., SANDU, A.V., ROSCA,

M., ANDRIAN, S., Rev. Chim. (Bucharest), 63, no. 1, 2012, p. 68.

21. HAMOUDA, I.M., J. Esthet. Restor. Dent., 23, no. 5, 2011, p.315.

22. BAJWA, N.K., PATHAK, A., ISRN Dent., 2014, 353926.

23. PRAKKI, A., CILLI, R., MONDELLI, R.F.L., KALACHANDRA, S., PEREIRA, J.C., J Dent., 33, no.2, 2005, p.91.

24. JANG, J.H., PARK, S.H., HWANG, I.N., Oper. Dent., 40, no.2, 2015, p.172.

25. BAGHERI, Y., GæK’aE, K., KAZAK, M., Dent. Mater., 23, no.8, 2007, p.944.

26. MAGANUR, P., SATISH, V., PRABHAKAR, A.R., NAMINENI, S., Int. J. Clin. Pediatr. Dent., 8, no.1, 2015, p.1.

27.TOFAN, N., ANDRIAN, S., NICA, I., STOLERIU, S., TOPOLICEANU, C., CHELARIU, R., BOLAT, M., PANCU, G., Rev. Chim. (Bucharest), 67, no.6, 2016, p.1144.

28. MUNTEANU, B., ANDRIAN, S., IOVAN, G., GHIORGHE, A., NICA, I., STOLERIU, S., Mat. Plast., 51, no.3, 2014, p. 279.

29. BADRA, V.V., FARAONI, J .J., RAMOS, R.P., PALMA-DIBB, R.G., Oper. Dent., 30, no.2, 2005, p.213.

30. STAVRIDAKIS, M.M., DIETSCHI, D., KREJCl, I., Oper. Dent., 30, no.1, 2005, p.118.

31. GHIORGHE, C.A., IOVAN, G., TOPOLICEANU, C., SANDU, A.V., ANDRIAN, S., Rev. Chim. (Bucharest), 64, no. 12, 2013, p.1436.

32. SIDERIDOU, I.D., KARABELA, M.M., VOUVOUDI, E.C., Dent. Mater., 27, no.6, 2011 p.598.

33. YAP, A.U., LOW, J.S., ONG, L.F.., Oper Dent., 25, no.3, 2000, p.170. 34.PANCU, G., IOVAN, G., GHIORGHE, A., TOPOLICEANU, C., NICA, I., TOFAN, N., STOLERIU, S., SANDU, A.V., ANDRIAN, S., Rev. Chim. (Bucharest), 66, no.12, 2015, p. 2051.

35. ANDRIAN, S., IOVAN, G., GHIORGHE, A.C., PANCU, G., GEORGESCU, A., ANTONESCU, D.N., STOLERIU, S., Rev.Chim. (Bucharest), 68, no. 1, 2017, p. 134

36. VALINOTI, A.C., NEVES, B.G., DA SILVA, E.M., MAIA, L.C., J. Appl. Oral Sci., 16, no.4, 2008, p.257.

37. GHIORGHE, C.A., STOLERIU, S., PANCU, G., TOPOLICEANU, C., SANDU, A.V., ANDRIAN, S., Rev. Chim. (Bucharest), 65, no. 9, 2014, p. 1021.

38. PANCU, G., ANDRIAN, S., MOLDOVANU, A., NICA, I., SANDU, A.V., STOLERIU, S., Mat. Plast., 51, no.4, 2014, p. 428.

$\overline{\text { Manuscript received: } 20.12 .2018}$ 